\title{
TEACHERS' PERCEPTION ON WRITING ASSESSMENT BASED ON 2013 CURRICULUM AT MAN 2 KEDIRI
}

\author{
Dewi Sari Pamungkas, Irwan Sulistyanto
}

\begin{abstract}
This research is purposed to describe teachers' perception on writing assessment based on 2013 curriculum at MAN 2 Kediri. This research used descriptive qualitative as the approach. The subject of this research is six English teachers of MAN 2 Kediri. There are two tools that were used to get the data namely questionnaire and interview. The results of this research are (1) in attitude assessment, almost all teachers of MAN 2 Kediri arrange the instrument in the right way, but the scoring rubric was not appropriate with 2013 curriculum (2) in knowledge assessment, all teachers of MAN 2 Kediri arrange the question and scoring rubric appropriately with 2013 curriculum (3) in psychomotor assessment, teachers arrange the question in psychomotor assessment in the right way but the choosing of question is not suitable for psychomotor assessment. For the scoring, all teachers use analytic rubric, but, do not concern the criteria in the scoring rubric. (4) most of teachers do not have any problems in the writing assessment. For the suggestions, teachers should add the description in scoring rubric for attitude assessment as the same with 2013 curriculum. Next, in choosing the question/task should be appropriate with the aspect that will be assessed. The last, teachers should determine the criteria for scoring rubric in knowledge and psychomotor assessment.
\end{abstract}

Keywords: 2013 curriculum, assessment, writing

\section{INTRODUCTION}

Writing is being a concern due to the usefulness in competing in globalization era. Writing has some important roles in education. According to Kellog in Fareed (2016) argued that writing is a cognitive process that test memory, thinking ability and verbal command to successfully express the ideas. One of the reason that writing is one of the basic skill in any jobs. Due to the importance of writing, teachers should prepare their teaching or class well. One of the important things to be prepared is assessment. According to Coombe (2018) assessment means a systematic process to improve students' language learning and development by evaluating and measuring collected data and information on students' language knowledge, understanding, and ability. Mousavi in Tran (2012) defined assessment as rating or approximating the level of someone's attributes. Huot and Neal (2006) argued that writing assessment is the technologies and practices used to evaluate students' writing and learning. Behizadeh and Engelhard (2011) stated that assessment of writing refers to an 
area of study that contains theories and practices that guide the evaluation of a writer's performance or potential through a writing task.

In the arranging assessment, school or teachers use 2013 curriculum as the guidance. Based on Permendikbud No. 23 tahun 2016 chapter 2, section 3 about the assessment aspect of students' learning outcome, the aspect that must be assessed in 2013 curriculum are attitude, knowledge and psychomotor. There are some steps in assessment. Based on Permendikbud No. 23 tahun 2016 about procedure of learning process and learning result assessment by teachers, the procedures of assessment divided into eight steps. It is from the preparation until the utilizing the report of assessment result. One of them is arranging the assessment. Arranging assessment is one of important principal in the learning process remaining that teachers is a facilitator in learning process who have the responsibilities to give the best education for the students. So that, this research aimed to describe the teachers' perception in writing assessment based on 2013 curriculum.

The objective of this research are (1) to describe the way how to arrange the instrument for assessing students' attitude (2) to describe the way how to arrange the questions/task on assessing students' knowledge in writing (3) to describe the way how to arrange the questions/task on assessing students' psychomotor in writing (4) to describe the way how to arrange the scoring rubric for assessment on students' attitude (5) to describe the way how to arrange the scoring rubric for assessment on students' knowledge in writing (6) to describe the way how to arrange the scoring rubric for assessment on students' psychomotor in writing (7) to describe the problem faced by teachers in assessing writing.

\section{Method}

The approach of this study is descriptive qualitative. The data collecting method is using questionnaire and interview. The questionnaire was divided into three part such as attitude, knowledge and psychomotor. For teachers there are 82 statements and for students, there are 16 statements. The interview, was designed for deputy head of curriculum with 12 questions. Second, was for students In collecting the data, researcher chose the location of research at MAN 2 Kediri. The data was gotten from three sources such as six English teachers, one deputy head of curriculum and ten students of MAN 2 Kediri. The procedure of the research was divided into three steps such as research preparation, research process and data analysis. Research preparation includes the getting permission from MAN 2 Kediri as the location of research. research process is the activity to collect the data by using questionnaire and interview. It is conducted via WhatsApp application due to pandemic of covid-19. Then, the data that heen gotten must be analyzed. It is analyzed by doing data display, data reduction and data verification.

\section{Result and Discussion}

After got the data, the researcher analyzed it and verify it by using triangulation. And the result based on the objective of the research is explained as follow: 


\section{Result}

1. The teachers way to arrange the instrument for assessing students' attitude in writing assessment

First, from the data of questionnaire about technique used, the researcher found that (1) observation technique is used by all teachers of MAN 2 Kediri (2) self-assessment is used by five teachers, one teacher do not use it (3) Peer assessment is only used by one teacher, while five teachers do not use peer assessment as the technique in attitude assessment. Second, the data from the questionnaire aspects in attitude assessment showed (1) spiritual aspect is used by two teachers, while four teachers do not use spiritual aspect in attitude assessment (2) social aspect is used by all teachers in arranging the attitude instrument.

Third, the finding in questionnaire about criteria data has result that devout worship criteria do not used by all teachers. Orderly pray criteria is used by five teachers, one teachers do not use it. Religious tolerance criteria is used by three teachers while two teachers do not use it. Gratitude criteria is used by all teachers. Greeting is used by one teacher, while five teachers do not use it. Polite criteria is used by all teachers. Caring criteria is used by all teachers. Self-confidence criteria is used by all teachers. Discipline criteria is used by all teachers. Responsibility criteria is used by all teachers. Caring for the environment is used by all teachers. Cooperation is used by one teacher, while five teachers do not use it. Responsive criteria is used by all teachers. Pro-active criteria is used by one teacher, five teachers do not use it. Beside that, from the interview answers, all teachers said that there are no other criteria that they used in attitude assessment.

The last is about the instrument form used in attitude assessment. From the data finding, researcher can found that the form of journal is used by five teachers, one teachers do not use it. The form of check list is used by four teachers, while two teachers do not use this. Rating scale is used by four teachers except two teachers.

2. The teachers way to arrange the question/task for assessing students' knowledge in writing assessment

From the data finding in questionnaire about technique used in knowledge assessment has result that multiple choice is used by all teachers. Essay is used by five teachers, while one teachers do not use it. Assignment is used by all teachers as the technique in knowledge assessment. Next, table 4.6 is about arranging the grid. The finding show the result that five teachers arrange the grid before making writing questions, while one teacher do not do it. When making the grid, all teachers representing the contents of the curriculum to be tested. The next result is all teachers answer that they make the grid component in detail, clearly, and easily understood. The last result from table 4.6 is all teachers answer that they set the question indicators clearly and can make questions according to the form of the questions which have been set.

Table 4.7 is about the component used in arranging the grid. The finding shows result that (1) type / level of school is used by all teachers (2) study programs / majors is used by all teachers (3) subject of lesson is used by two teachers, while four teachers do not use it (4) school year is used by all teachers 
(5) referenced curriculum is used by five teachers, while one teachers do not use it (6) time allocation is used by all teachers (7) total of questions is used by all teachers (8) question form is used by all teachers (9) basic competencies is used by all teachers (10) class and semester is used by all teachers (11) material is used by all teachers (12) indicator is used by all teachers (13) cognitive level is used by three teachers, while three others do not use it (14) question number is used by all teachers.

The last, teacher should paying attention into cognitive level when arranging the questions. The finding in table 4.8 show the result which all teacher answer that they pays attention to all cognitive level in arranging the question of writing. Beside the questionnaire, the interview show the result answer that five teachers in arranging the question, they only pays attention in the level of question, it is low to hard level. While one teacher arrange the question by see the syllabus first, then determine the percentage of easy, medium, difficult item, and the last is make the grid. More, all teachers had an opinion that there is no other component in arranging the grid except in questionnaire.

3. The teachers way to arrange the question/task for assessing students' psychomotor in writing assessment

Table 4.9 about techniques used showed that performance technique is used by one teacher only, while other teachers do not use it. Project technique is used by all teachers. Portfolio technique is used by three teachers, while three other teachers do not use it. Product technique is used by all teachers. More, from the interview question number 6 has result that five teachers give example of sentence of present perfect continuous as the question of performance technique in writing. While from number 7 until 9, five teachers teacher never classify the question into portfolio technique, project technique and product, they just classify from low to hard and based on taxonomy bloom as the same with answer of number 5. One teacher has answer for number 6 until 9 and the results are (1) the example question in performance is nothing (2) the example of question in project technique is compose a hortatory text based on the study that students' make (3) the example of question of portfolio technique is submit some study that students' make in some topic (4) the example of question of product technique is submit study and argument that students' make for the topic.

The result of Table 4.10 showed that (1) all teachers arranges the grid before making writing questions (2) one teacher makes a grid by representing the contents of the curriculum to be tested, while five teachers don't (3) all teachers make the grid component in detail, clearly, and easily understood (4) three teachers set the question indicators clearly and can make questions according to the form of the questions which have been set, except other three teachers.

Table 4.11 has result that (1) type / level of school is used by all teachers (2) study programs / majors is used by all teachers (3) subject of lesson is used by one teacher, while five teachers do not use it (4) school year is used by all teachers (5) referenced curriculum is used by one teacher, while five teachers do not use it (6) time allocation is used by all teachers (7) total of questions is used by three teachers (8) question form is used by all teachers (9) basic competencies is used 
by all teachers (10) class and semester is used by all teachers (11) material is used by all teachers (12) indicator is used by all teachers (13) cognitive level is used by three teachers, while three others do not use it (14) question number is used by all teachers. The last, teacher should paying attention into cognitive level when arranging the questions. Table 4.12 show that all teachers pay attention in three cognitive levels in arranging the questions for psychomotor assessment.

4. The teachers way to arrange the scoring rubric for assessing students' attitude in writing assessment

The result of data is gotten from table 4.13 about the questionnaire answer in scoring rubric of attitude assessment. The results are (1) five teachers except one teacher give a predicate for scoring attitude assessment (2) all teachers use very good, good, good enough and less as the predicate in scoring attitude assessment (3) two teachers give the description of the behavior of each predicate, while four teacher do not give it.

5. The teachers way to arrange the scoring rubric for assessing students' knowledge in writing assessment

Scoring rubric for knowledge assessment is divided into two such as objective and non-objective scoring rubric. The result is gotten from table 4.14 from the questionnaire answer about scoring rubric of knowledge assessment. It shows that teacher all teachers except teacher 6 use objective scoring in assessing students' knowledge. Then, the non-objective scoring is used by all teachers. Last, all teachers determine the assessment criteria in non-objective scoring. More, from the interview, shows the result that five teachers use criteria remembering, understanding, applying, analyzing and creating in non-objective scoring. While one teacher said that there are no criteria in non-objective scoring.

6. The teachers way to arrange the scoring rubric for assessing students' psychomotor in writing assessment

There are two kinds of rubric that can be used by the teachers in assessing students psychomotor. The kinds of scoring rubric is holistic rubric and analytic rubric. From table 4.15 about the questionnaire answer in scoring rubric of psychomotor assessment has result that (1) all teachers do ot use holistic rubric in assessing psychomotor aspect (2) all teachers use analytic rubric in assessing psychomotor aspect. More, from the answer for interview number 10, researcher explain that all teachers do not use other format and there are no criteria in both holistic and analytic rubric.

7. Teachers Problems in writing assessment

From the answer of interview of number 11, the results are (1) five teachers do not face any obstacle in arranging the instrument and question for attitude, knowledge and psychomotor aspect in writing. (2) one teacher make an instrument and question/task as simple as possible for students is not easy. The last is the interview answer of number 12 show the result that all teachers do not 
face any problem or obstacles in arranging the scoring rubric for attitude, knowledge and psychomotor in writing.

\section{Discussion}

1. The teachers' way to arrange the instrument for assessing students' attitude in writing assessment.

Based on the result of data analysis, the researcher found that $66,6 \%$ teachers of MAN 2 Kediri pays attention to the observation and self-assessment techniques. Verified by the curriculum staff, that in MAN 2 Kediri conduct an attitude assessment by using all technique in 2013 curriculum. For addition, from the result of students' questionnaire, it can be said that teachers apply the observation and self-assessment for students. More, 66,7 \% teachers of MAN 2 Kediri pays attention in the using of spiritual aspect and social aspect in attitude assessment. According to the 2013 curriculum, in the attitude assessment should use all aspect of attitude assessment, but four teachers that do not use spiritual aspect in attitude assessment. Based on the interview from curriculum staff, there are two aspects that should be assessed, those are spiritual aspect and social aspect. There are 70,24\% teachers who use the criteria in the questionnaire choice. According to 2013 curriculum, the form of instrument for attitude assessment is divided into three such as journal, check list, rating scale. Based on the interview from curriculum staff, she said that in MAN 2 Kediri the form of attitude assessment is journal, check list and rating scale. From the data, researcher found 72,2\% teachers of MAN 2 Kediri pays attention the using of form in the arranging instrument for attitude assessment.

2. The teachers way to arrange the question/task for assessing students' knowledge in writing assessment

Based on 2013 curriculum the activity that should be done such as determine the technique, arrange the grid, and arrange the question based on the grid that has arranged. Based on interview with curriculum staff, the way for arranging the question is making the grid based on the syllabus then arranging the question. Researcher found that $99,4 \%$ teachers use almost all techniques in assessment of knowledge aspect. 91,6\% teachers of MAN 2 Kediri pay attention to the grid arrangement before arranging the question. Third, in the arranging question, teachers should determine the level cognitive of the questions. Then, the researcher found that $100 \%$ teachers of MAN 2 Kediri pay attention in the determining the cognitive level in the arranging the question. It is verified with the interview section that all teachers done the arrangement of question with the right way and related with the 2013 curriculum. From the students' questionnaire result, they have done all the form of questions, so it can be said that teachers have applied all techniques in knowledge assessment.

3. The teachers way to arrange the question/task for assessing students' psychomotor in writing assessment

Based on 2013 curriculum the activity that should be done such as determine the technique, arrange the grid, and arrange the question based on the 
grid that has arranged.. Based on the interview with curriculum staff, to arrange the questions, teacher should arrange the grid from the syllabus then arrange the questions. From the result of students' questionnaire, teachers asked the students to do project, portfolio and product assessment. Researcher found that $66,6 \%$ teachers are pay attention in the techniques in assessment of psychomotor aspect. Almost all teachers said that they use an activity to make a sentence of present perfect continuous, but actually making a sentence is classified in the knowledge assessment. More, almost all teachers said that they never classify the question/task into portfolio, project, and product technique. Second, 80,5\% teachers of MAN 2 Kediri pay attention to the grid arrangement before arranging the question. Third, in the arranging question, teachers should determine the level cognitive of the questions. Then, the researcher found that $100 \%$ teachers of MAN 2 Kediri pay attention in the determining the cognitive level in the arranging the question. It is verified with the interview section that all teachers done the arrangement of question with the right way and related with the 2013 curriculum.

4. The teachers way to arrange the scoring rubric for assessing students' attitude in writing assessment

In the arrangement of scoring rubric, teachers need to pay attention in the some things in the attitude assessment. According to the 2013 curriculum, there are two aspects in scoring rubric of attitude assessment such as predicate and description. It means that teachers give the predicate with $A, B, C$ or $D$ then teachers should give the description based on the predicate they gave. Based on the interview with curriculum staff, teachers are free to arrange the scoring rubric based on the subject of lesson they teach. First, determine the predicate in the scoring rubric. Second, determine the description in every predicate. From the result of data analysis, researcher found that 96,6\% teachers of MAN 2 Kediri pay attention into the predicate in scoring rubric. It means that almost all teachers use predicate in the scoring rubric. But, only $33.3 \%$ teachers use description in the scoring rubric. So, it can be conclude that teachers of MAN 2 Kediri using predicate in the arrangement of scoring rubric but only some teachers use description on it.

5. The teachers way to arrange the scoring rubric for assessing students' knowledge in writing assessment

Based on 2013 curriculum, the scoring rubric for knowledge assessment divided into two. The scoring rubric for knowledge assessment are objective scoring rubric and non-objective scoring rubric. From the result of data analysis, researcher found that $94.4 \%$ teachers use both objective and non-objective scoring. But, when the researcher ask in interview section about what criteria in the non-objective scoring, five teachers answer that they do non-objective scoring of writing by using some criteria such as remembering, understanding, applying, and creating. Those criteria are not suitable for the non-objective scoring rubric in this case is scoring for writing. So, it can be concluded that in the arrangement of scoring rubric for knowledge assessment, teachers use both objective and nonobjective scoring, but the using of criteria for non-objective rubric is not 
appropriate with the scoring rubric for writing assessment especially in nonobjective scoring rubric.

6. The teachers way to arrange the scoring rubric for assessing students' psychomotor in writing assessment

In the arranging scoring rubric for writing assessment in psychomotor aspect, there are two kinds of rubric that can be used. Those are holistic and analytic rubric. From the result of data analysis, through questionnaire the researcher found there is no teacher who choose holistic rubric. It can be said that $100 \%$ teachers or all teachers use analytic rubric in the scoring of writing assessment in the psychomotor aspect. But, in the interview section about what criteria that they use in the rubric, all teachers said there is no criteria. It is very contradictive with their chosen in the questionnaire, whereas, teachers should determine the criteria for analytic rubric in scoring writing. So, it can be conclude that teachers of MAN 2 Kediri arrange the analytic rubric for assessing students' psychomotor especially in writing. More, they do not determine any criteria for analytic rubric for scoring psychomotor in writing assessment.

7. The teachers problems in writing assessment

From the result of data analysis, through the interview section about the problem that is faced by teachers in writing assessment, the researcher found that five teachers claimed that they do not have any obstacles or problems in the writing assessment especially in the arranging of instrument, question, and scoring rubric for attitude, knowledge and psychomotor assessment. But, there is one problem that faced by one teacher. The problem is not easy to make the scoring rubric understandable by the students. So, it can be said that almost all teachers of MAN 2 Kediri do not face any obstacles or problems in the arrangement of writing assessment.

\section{Conclusion}

Conclusion consist the final result from the research. it is concluded based on the topics of the research. After analyzed and verified the data with triangulation, it can be concluded that (1) The teachers way in arranging the instrument for writing assessment in attitude aspect use observation and selfassessment techniques. Most of teachers do not use spiritual aspect in the assessing of attitude, but teachers use the criteria for spiritual aspect. it is very contradictive with the statement before. In the arranging of instrument, most of them use journal, check list and rating scale. (2) In arranging the question/task for knowledge aspect in writing assessment, 99,4\% teachers use almost all techniques in assessment of knowledge aspect. 91,6\% teachers of MAN 2 Kediri pay attention to the grid arrangement before arranging the question. $100 \%$ teachers of MAN 2 Kediri pay attention in the determining the cognitive level in the arranging the question. (3) In arranging the question/task for psychomotor aspect in writing assessment, 66,6\% teachers are pay attention in the techniques in assessment of psychomotor aspect. 80,5\% teachers of MAN 2 Kediri pay attention to the grid arrangement before arranging the question. 100\% teachers of MAN 2 
Kediri pay attention in the determining the cognitive level in the arranging the question. (4) 96,6\% teachers of MAN 2 Kediri pay attention into the predicate in scoring rubric. But, only $33.3 \%$ teachers use description in the scoring rubric. It can be said that the teachers way to arrange the scoring rubric for assessing students' attitude do not follow form of 2013 curriculum. (5) $94.4 \%$ teachers of MAN 2 Kediri use both objective and non-objective scoring. But, they do not know what criteria that they use in the scoring of both objective and non-objective scoring. (6) $100 \%$ teachers or all teachers use analytic rubric in the scoring of writing assessment in the psychomotor aspect. But, they do not choose the criteria for it. (7) Five teachers do not have any obstacles in the writing assessment. But, there is one problem that faced by one teacher. The problem is not easy to make the scoring rubric understandable by the students.

\section{References}

Behizadeh, N. and George E. Jr. (2011). Historical View of the Influenced of measurement and writing theories on the practice of writing assessment in the United states Assessing writing 16 in www.wikipedia.org access on Friday, May 08, 2020 at 09.13 AM.

Coombe, C. (2018). An A to $Z$ of Second Language Assessment: How Language Teachers Understand Assessment Concepts. London, UK: British Council.

Direktorat Pembinaan Sekolah Menengah Atas, Direktorat Jenderal Pendidikan Dasar dan Menengah. 2017. Panduan Penilaian oleh Pendidik dan Satuan Pendidikan Sekolah Menengah Atas. Jakarta: Kementerian Pendidikan dan Kebudayaan Republik Indonesia.

Fareed, M., Ashraf, A., Bilal, M. (2016). ESL Learners' Writing Skills: Problems, Factors and Suggestions. Journal of Education and Social Science.

Huot, B \& Neal M. (2006). Writing Assessment: A techno-history. In C, A. MacArthur, S. Graham, \& J. Fitzgerakd (Eds.), Handbook of Writing Research. New York, NY: Guilford Press.

Menteri Pendidikan dan Kebudayaan Republik Indonesia. (2016). Salinan Peraturan Menteri Pendidikan dan Kebudayaan Republik Indonesia Nomor 23 Tahun 2016nTentang Standard Penilaian Pendidikan. Jakarta: Kementerian Pendidikan dan Kebudayaan Republik Indonesia.

Tran, T. H. (2012). Second Language Assessment for Classroom Teachers. Usa: Missouri University 